\title{
The Dynamics of Indonesia's Current Account Deficit : Analysis of the Impact of Exchange Rate Volatility
}

\author{
Rudi Purwono', Karima Mucha ${ }^{2}$, M. Khoerul Mubin ${ }^{3}$ \\ Received: February 21, 2018. Revised: March 31, 2018. Accepted: May 5, 2018.
}

\begin{abstract}
In the globalization and free trade era, the current account deficit problem is a common phenomenon experienced by most countries, both developing and developed countries. Also with managed floating regime of exchange rate, it becomes very important to analyze the dynamics of current account balance which determine the trade. The deficit condition has lasted for four years in Indonesia, as well the deficit value above the value of the surplus that has been experienced during the period 2005-2011. This study is firstly aim to examine the condition of the deficit which happens in the export and import, manufactured goods and oil and gas, whether related to the transaction of goods and services. We try to build a predicted model which near the actual. Then, the focuses examines an exchange rate volatility impact on current account deficit. The model used in this research is a simultaneous model of Indonesia current account deficit from 2005 to 2014. The simulation result indicated that depreciation increase surplus to current account deficit. The decrease of export manufactured goods (non oil and gas) higher than the increase of import. For the oil and gas sector, depreciation of the rupiah against the US dollar results in an increased burden of higher oil and gas imports due to import transactions.
\end{abstract}

Keywords: Current Account Deficit, Exchange Rate Volatility, Simultaneous Model, Balance of Payment, Exchange Rate, Indonesia.

JEL Classification Code: F10, F31, H62.

\section{Introduction}

The phenomenon of current account deficit in Indonesia get a serious attention in recent years. The deficit conditions emerged in mid-2012 when Indonesia's trade balance pressure several consecutive months (April-May-June 2012) The impact during 2012 Indonesia's economy in deficit throughout the year, especially in the balance of trade (total $\$ 1.96$ billion). This induces current account of Indonesia recorded the deficit to reach $\$ 24.4$ billion, or about $2.8 \%$ of the Gross Domestic Product (GDP) in 2012. The widening deficit of current account continues for three consecutive years until 2015 that reaches each of USD 28.5 billion (3.26\% of GDP). In 2013 , stood at $\$ 27.5$ billion (3.09\% of GDP) in 2014 and amounted to USD 17.65 billion (2.05\% of GDP) in 2015. The widening of deficit caused by the global economic uncertainty (global imbalances) that suppress demand for

1 First Author, Fakultas Ekonomi dan Bisnis UNAIR, Universitas Airlangga, Indonesia. Email: rudipurwono@feb.unair.ac.id

2 Fakultas Ekonomi dan Bisnis UNAIR, Universitas Airlangga, Indonesia. Email: karimamuchacha@gmail.com

3 Corresponding Author, Fakultas Ekonomi dan Bisnis UNAIR, Universitas Airlangga, Indonesia [Postal Address: Fakultas Ekonomi dan Bisnis UNAIR, Universitas Airlangga, Jalan Airlangga No. 4, Airlangga, Gubeng, Surabaya, 60286, Indonesia] Email: mkmubin@feb.unair.ac.id
Indonesian exports and commodity prices, while at the same time the high domestic demand for investment and consumption have pushed imports.

In the era of globalization and free trade, the problem of the deficit in the current account is actually a common phenomenon which is experienced by most countries, both developed and developing countries. Along with the development of economic activity between countries, the openness of the economy has an impact on a country's balance of payments involving trade flows and capital flows including Indonesia.

Theoretically, trade flows can be affected by exchange rate policies in an effort to maintain the competitiveness of exports and reduce imports to reduce the current account deficit. Effect of exchange rate policy on the economy can be seen through the two sides, namely the demand and supply.

On the demand side, the depreciation of the rupiah against the US dollar, for example, will cause the price of foreign goods is relatively higher than the price of domestic goods. This will impact on increasing domestic demand for goods, both domestic demand and foreign demand (exports is increased). Analysis of the demand side is enriched with the concept of price elasticity of Marshall-Lerner Condition, in which the exchange rate depreciation will increase net exports if the amount of the price elasticity of exports and imports is greater than one. 
While the supply side, the depreciation of the real exchange rate (for example, the rupiah against the US dollar) would increase the cost of imported raw materials, which in turn can lead to a decrease in production output and will trigger a rise in general prices (inflation). The interaction between the demand side and the supply side will directly affect international trade flows, which in the macro indicators reflected in the trade balance (balance of trade) of a country (Krugman, 2010).

Table 1 below presents data from the World Development Indicator (WDI) which is published by the World Bank regarding the condition of the balance of payments by a number of countries in the world in the last period during 2010-2014. A number of countries reported having a surplus in the balance of payments to GDP ratio is about $10-50 \%$, including East Timor, the Russian Federation, Saudi Arabia, Singapore, Japan, Malaysia, and the Philippines. On the other hand, some countries have experienced the current account deficit, is well underway temporally and continued over the last ten years. In the ASEAN region, this temporal deficit conditions experienced by the country of Indonesia, Thailand, Cambodia, Laos, Myanmar, and Vietnam. Meanwhile, Australia, the United States and the United Kingdom reported a deficit continuously during the years 2005-2014, with the value of the deficit ranged between $1-6 \%$ of the GDP of the country concerned.

Table 1. Current Account Deficit in Some Countries, 2010-2014

\begin{tabular}{|l|c|c|c|c|c|}
\hline \multicolumn{1}{|c|}{ Countries } & $\mathbf{2 0 1 0}$ & $\mathbf{2 0 1 1}$ & $\mathbf{2 0 1 2}$ & $\mathbf{2 0 1 3}$ & $\mathbf{2 0 1 4}$ \\
\hline Australia & -3.918 & -3.208 & -4.432 & -3.201 & -2.801 \\
\hline Brunei Darussalam & n.a & n.a & 33.526 & n.a & n.a \\
\hline China & 3.937 & 1.816 & 2.546 & 1.926 & n.a \\
\hline United Kingdom & -2.617 & -1.665 & -3.741 & -4.489 & -5.912 \\
\hline Hong Kong SAR, & 7.003 & 5.556 & 1.579 & 1.506 & 1.870 \\
\hline Indonesia & 0.681 & 0.189 & -2.660 & -3.197 & -2.859 \\
\hline India & -3.191 & -3.405 & -4.994 & -2.644 & -1.514 \\
\hline Japan & 4.020 & 2.194 & 1.010 & 0.836 & 0.522 \\
\hline Cambodia & -3.647 & -3.706 & -7.385 & -10.555 & $n . a$ \\
\hline Korea, Rep. & 2.636 & 1.551 & 4.157 & 6.215 & 6.326 \\
\hline Sri Lanka & -2.169 & -7.799 & -6.750 & -3.780 & -2.693 \\
\hline Mexico & -0.478 & -1.136 & -1.338 & -2.412 & -2.062 \\
\hline Myanmar & $n . a$ & $n . a$ & -1.686 & -1.923 & $n . a$ \\
\hline Malaysia & 10.907 & 11.581 & 6.112 & 3.746 & $n . a$ \\
\hline Pakistan & -0.763 & -1.045 & -1.042 & -1.901 & -1.436 \\
\hline Philippines & 3.597 & 2.517 & 2.777 & 4.184 & 4.445 \\
\hline Russian Federation & 4.423 & 5.107 & 3.536 & 1.674 & 3.140 \\
\hline Saudi Arabia & 12.671 & 23.681 & 22.449 & 18.196 & 10.307 \\
\hline Singapore & 23.663 & 21.993 & 17.167 & 17.894 & 19.090 \\
\hline Thailand & 3.119 & 2.584 & -0.398 & -0.976 & 3.586 \\
\hline Timor-Leste & 178.949 & 208.909 & 215.434 & 162.809 & 71.273 \\
\hline United States & -2.953 & -2.967 & -2.782 & -2.247 & -2.236 \\
\hline
\end{tabular}

Source: World Bank, World Development Indicator, 2015
In this study, researchers tried to explain how changes or the volatility of the rupiah / US dollar against the current account Indonesia. Economy of Indonesia increasingly open since 2010 is marked by several free trade agreements such as the ACFTA. With the opening of trade and capital flows in Indonesia, that the conditions of the current account is also increasingly volatile. That is, the current account Indonesia began to be influenced by events that occur outside Indonesia. Therefore it is important to know how the influence of external factors, especially as changes in the value of the rupiah against the US dollar to the current account. From this research, it is expected to be known whether these fluctuations are positive or negative for the current account position of Indonesia.

The methodology used is simultaneous models that allow researchers to describe how changes in the value of the rupiah against the US dollar to the current account deficit, either direct or indirect (through a particular transmission phases). Current account balance is the description of the general equilibrium of an economy, which represents the balance between the domestic economy and domestic economic linkages with the global economy (Mann, 2002). The current account balance is formed by many variables with respect to each other. Therefore, in this study used simultaneous models. The composition of the writing of this study as follows. Background the first part of the form, followed by the Study Objectives and Methodology in the second and third parts. Section four discusses the results of the study and analysis. Conclusions and Closing presented in the fifth part.

\section{Literature Review}

In general, the main component in the current account are: trade balance (balance of trade), investment income (earnings from investment), and transfer cash. Following the notation is common, the components of the current account is expressed as follows. Exports of goods and services, denoted as $X$, and imports of goods and services components are stated as $\mathrm{M}$. Net income (net) from abroad expressed by notation NY, and net transfers (net current transfers) denoted by NCT, the balance sheet or balance sheet equation run (Current account Balance / CAB) is expressed as follows.

$$
\mathrm{CAB}=\mathrm{X}-\mathrm{M}+\mathrm{NY}+\mathrm{NCT}
$$

Equation (2.1) above is an indicator of a country's economic performance. The first component is the value of trade between the countries concerned with foreign parties, namely component net trade (export-import). Components 
of the trade balance is also recognized empirically is the largest component in the current account, particularly in developing countries. Imbalances in the trade balance, can be used as an indication of the changes that might occur at the prevailing exchange rate. This hypothesis is the basis why the components of the current account is a special concern of the policy makers, Central Bank and market analysts.

According to Mann (2002), the Current Account or Current Account is not a fundamental factor in boosting the economy of a country. However, this current account balance can describe the general (equilibrium) that occurs from the interaction of many factors in the economy, namely the interaction between national saving to investment; the interaction between economic growth and trade openness; interaction with the flow of capital investment (capital flows); the interaction between price, rate of return, and the exchange rate; and the interaction between fiscal and monetary policy. General equilibrium model that is sketched on the current account describes the relationship between the domestic economy and the international economy.

In analyzing the current account general, there are several perspectives or which may be mentioned approach is used. The first approach, the analysis of the current account which describes the balance of the domestic economy, which is based on national income and gross income. This analysis illustrates that domestic savings and investment that is to be reflected on the balance between the current account and trade (Mann, 2002). More clearly illustrated in the following equation.

\section{Domestic Private Saving + Trade Deficit $=$ Private Investment + Gov. Budget Deficit}

Equation 2.2 above shows that domestic production should be the same as the investment incurred to finance the production of the remedy. Domestically, the production that is obtained from the use of national savings as capital and goods and services acquired from trading, together with investment and government budgets are used to finance domestic production. Left of the equations describing the flow of goods, while the right depicts capital flows. Factors that affect the four variables in the equation above can cause the deficit or imbalance in the current account.

Using the perspective of Marquez and Ericsson (1993), the growth of national income and the change of the domestic price level are relatively to encourage trade or flows of goods and services. Exports grow rapidly as incomes other countries (foreign income) also increase, and the price of export goods and services are relatively to domestic prices cheaper. For imports, it will grow faster if domestic demand growth and also in domestic prices are relatively to the price of imported goods and services declined. The illustration depicts that world GDP growth as well as growth in domestic GDP and the exchange rate also affect the balance of trade. The balance of trade can describe the balance of domestic production, which can be reflected in the current account balance (Mann, 2002).

According to Krugman (2010), the current account balance can be seen as a country of export demand (demand from overseas against the products of the country) reduced by import demand (demand of the country against another country's products). There are two main factors that always affect the current account balance, i.e. the real exchange rate of the domestic currency against foreign currencies (the price of a number of overseas spending measured in domestic spending) and net domestic income.

Therefore, it can be stated that the current account of a country is a function of the real exchange rate of its currency, namely $q=E P * / P$, and net national income, or commonly given the symbol $\mathrm{Yd}$.

$$
C A=C A\left(E P^{\star} / P, Y d\right)
$$

As the above equation, the price in domestic currency is a number of typical spending overseas and domestic, each of which is $E P$ * and $P$, while $E$ (nominal rate) is the price of foreign currency which is expressed in domestic currency. $P$ * is the foreign price level, there is no $P$ is the domestic price level. The real exchange rate, $\mathrm{q}$, is the price of a number of foreign products are measured in units of the domestic product, $\left(q=E P^{\star} / P\right)$.

Changes in the real exchange rate turns always affect the current account, because these changes reflect the prices of domestic goods and services relative to goods and services abroad. The net revenue effect transactions running through its effects on domestic customers in total expenditure, where the influence of the real exchange rate and net income of the working separately through the national export demand, $\mathrm{X}$, and the demand for imports, $\mathrm{M}$.

In order to understand how changes in the relative price of national output that affects the current account, we need to know the effects on $X$ and $M$. If the $E P * / P$ to increase, for example, are relatively foreign products become more expensive than domestic products: Each unit output domestic currently can only buy fewer foreign output. Consumers abroad would immediately response to shifting these prices by increasing their demand for domestic exports. This reaction further enhances the $X$ and it tend to improve the position (balance) the domestic current account.

The influence caused by a rise in the real exchange rate is equal to import more complicated. Domestic consumer's price responses to the shift by buying fewer foreign products, the more expensive it is. However, this reaction does not guarantee imports will decrease. $M$ is the value of imports 
are measured in domestic output, rather than from volume of foreign products are imported. Hence, the rise EP * / P tends to increase the value of each imported (measured in units of domestic output), so when there is an increase in the EP * / $P$, imports can actually increase (when measured in units of domestic output) even if it is measured in units of output the overseas imports declined. Then all rise EP * / P can increase or, conversely, reduce imports. That means the effect of changes in the real exchange rate to the current account, CA, is uncertain.

Improvement or reduction of the current account depends on the impact of changes in the real exchange rate which is dominant; the impact on the volume of consumer spending shift the quantity of exports and imports, or its impact on the value that changed the relative weights of the domestic output of a number of foreign imports. If the impact caused by a change in the real exchange rate is always greater in volume than value, then a real depreciation will improve the current account is the owner of the currency countries, while the real appreciation will exacerbate the transaction as it goes.

An empirical studies related to the phenomenon of deficit in the current account in general are using panel data analysis, and made in the period 1980-2000. The studies in question include: Khan and Knight (1983), Debelle and Faruqee (1996) Ferretti and Razin (1998), Calderon, Chong and Loayza (2002), Chinn and Prasad (2003), Gruber and Kamin (2007), Chinn and Ito (2007 and 2008). A number of other studies, focusing on one particular country such as the study of Freund and Warnock (2005), which examines the current account deficit in the United States, Özmen and YolcuKaradam (2014), which examines the deficit in the country of Turkey, Satsangi and Sangar (2013) which examines the deficit in the country India, during the years 1991-2003.

For studies that examine some of the countries in the data analysis panel, generally report the following matters. First, the greater the result of deficit in the current account, it will require increasingly long time return to the equilibrium position. Deficit ratio greater than $5 \%$ of GDP, during the economic recovery period will be followed by slower economic growth. Second, the current account deficit which is dominated by the goods account deficit was found to be accompanied by a depreciation of the exchange rate, and the period for the balance required is relatively longer than the deficit incurred by capital transactions. Thirdly, it is generally not found sufficient evidence that countries with deficits of more than five years due to the following: the ratio of foreign debt to GDP is high enough, experienced capital net inflow, the ratio of trade to GDP is high enough or in a period of adjustment current account (Freund \& Warnock, 2005).

For studies that focus on a particular countries, these are generally examine the determinants of the deficit, using time series data quarterly, analysis Granger Causality or Vector
Auto Regressive (VAR), and analyze its impact on macroeconomic variables (Freund \& Warnock, 2005). Studies of Satsangi and Sangar (2013) examine the links between the current account deficits with the socioeconomic variables in India. By using the Granger Causality test, the researchers find the causality one way and two ways relationship crime rate and level of corruption against the current account deficit that occurred in India.

\section{Methodology}

The methodology used in this study is a descriptive analysis of the empirical data relating to the situation in Indonesia. These data are presented in tables or graphics, and subsequently for the purposes of the simulation, conducted estimation of simultaneous equations relating to the condition of the current account in Indonesia. The sequence begins with the equation estimates the current account, by describing the components of the merchandise trade balance. The estimation results of simultaneous equations and the simulation results of the study are presented in the next section.

In this study, the selection of variables based on multiple models of the equation use, the theory, as well as some earlier research. In a simultaneous equation model is used, there are 9 exogenous variables and 11 endogenous variables. Overall there are 20 variables used in this study. The variables are presented in Table 2 below.

Table 2. Variables Identification

\begin{tabular}{|c|l|l|}
\hline No. & \multicolumn{1}{|c|}{ Variables } & \multicolumn{1}{c|}{ Notes } \\
\hline 1 & XM & Export of Oil and Gas \\
\hline 2 & XNM & Export of Non Oil and Gas \\
\hline 3 & GDP_WORLD & World Economic Growth \\
\hline 4 & WOP & Crude Oil Price \\
\hline 5 & GDP_CAP & GDP per Capita \\
\hline 6 & P_MINAS & Indonesia Crude Oil Price \\
\hline 7 & ER & Exchange Rate Rupiah/dollar AS \\
\hline 8 & GDP_INDO & Indonesia's GDP Growth \\
\hline 9 & JIBOR & Jakarta Interbank Offered Rate \\
\hline 10 & RCA & Revealed Comparative Advantage \\
\hline 11 & MM & Import of Oil and Gas \\
\hline 12 & MNM & Import of Non Oil and Gas \\
\hline 13 & Q_MC & Number of Motor Vehicle \\
\hline 14 & LIFTING & Crude Oil Production (Quantity) \\
\hline 15 & P_BBM & BBM Price (Bahan Bakar Motor, Motor Fuel) \\
\hline 16 & FDI & Foreign Direct Investment \\
\hline 17 & INF & National Inflation \\
\hline 18 & POP & Population \\
\hline 19 & W & Wage \\
\hline 20 & Q_M & Total Output of Industry \\
\hline
\end{tabular}




\section{Simulation Model}

The model used is a model of simultaneous equations consist of several equations. The specifications of the model are as follows:

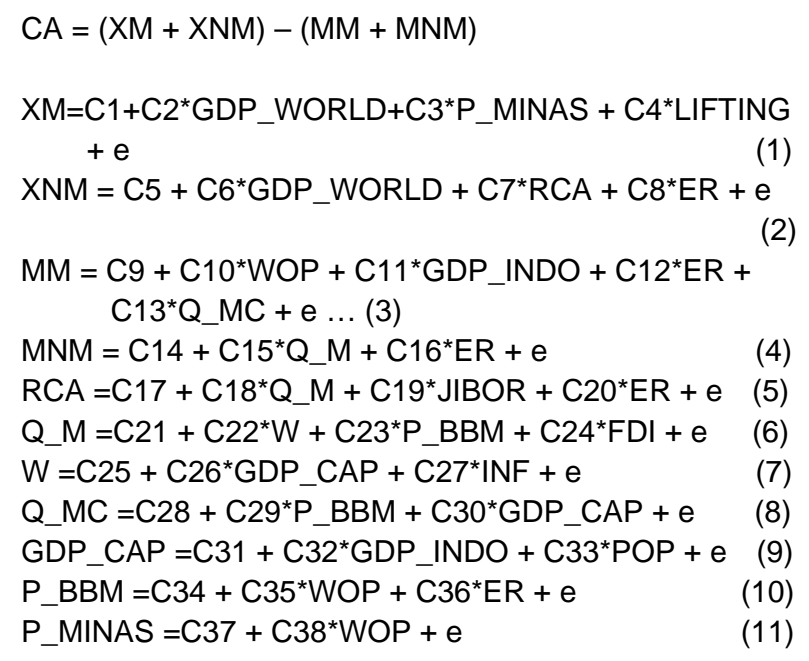

\section{Model Identifications}

To identify the model, condition and rank order use condition or necessary and sufficient condition (Pindyck \& Rubinfeld, 1998). A necessary condition for an unidentified equation is that the number of independent variables that exist in the system but not in the equation must be at least equal to the number of endogenous variables in the existing system the equation minus one. If $\mathrm{K}$ is the number of independent variables in the system that are not in the equation, and $G$ is the number of endogenous variable in the existing system in the equation. The criteria to declare an equation is Unidentified, Just Identified, and Over Identified are:

$$
\begin{aligned}
& {[\mathrm{K}<\mathrm{G}-1 \text { Unidentified }]} \\
& {[\mathrm{K}=\mathrm{G}-1 \text { Just Identified }]} \\
& {[\mathrm{K}>\mathrm{G}-1 \text { Over Identified }]}
\end{aligned}
$$

Identification of the process of the next equation is the fulfillment of the criteria sufficient condition (Pindyck \& Rubinfeld, 1998). The sufficient condition would only confirmed that among the independent variables in the equation that there is no perfectly correlated. Criteria for the Rank Condition is as follows:

If Rank [Ri] M - 1 dan Rank [Ri* $\Delta]<M-1$ Unidentified If Rank [Ri] $M-1$ dan Rank [Ri $* \Delta]<M-1$ Just Identified
If Rank [Ri] M - 1 dan Rank $[R i * \Delta]<M-1$ Over Identified

Where $M$ is the number of endogenous variable in the system of equations and $\mathrm{Ri}$ is a matrix equation of all. It declares a variable endogenous and exogenous that is not in the equation is concerned, as well as stating the coefficient matrix of all the variables of endogenous and exogenous formed based system structural equation that has been transposed. To establish a Reduced Form then simply follow the rules given by Pindyck and Rubinfeld (1998) as follows: Short Form for structural equation written in [1] through [11] are:

$$
\begin{aligned}
\mathrm{XM}= & \pi 1^{*} \text { GDP_WORLDt }+\pi 2^{*} \text { LIFTINGt }+\pi 3^{\star} \text { ERt }+ \\
& \pi 4^{*} \text { WOPt }+\pi 5^{\star} \text { GDP_INDOt }+\pi 6^{*} \text { JIBORt }+\pi 7^{\star} \text { FDIt }+ \\
& \pi 8^{*} \text { INFt }+\pi 9^{*} \text { POPt }+ \text { et }
\end{aligned}
$$

$\mathrm{XNM}=\pi 19^{\star}$ GDP WORLDt $+\pi 20^{\star}$ LIFTINGt $+\pi 21^{\star}$ ERt + $\pi 22 *$ WOPt $+\pi 23 *$ GDP_INDOt $+\pi 24 *$ JIBORt + $\pi 25^{\star} \mathrm{FDIt}+\pi 26^{\star} \mathrm{INFt}+\pi 27^{\star} \mathrm{POPt}+$ et

$\mathrm{MM}=\pi 37^{\star} \mathrm{GDP}$ WORLDt $+\pi 38^{\star}$ LIFTINGt $+\pi 39 *$ ERt + $\pi 40 *$ WOPt $+\pi 41 *$ GDP_INDOt $+\pi 42 *$ JIBORt + $\pi 43^{\star} \mathrm{FDIt}+\pi 44^{\star} \mathrm{INFt}+\pi 45^{\star} \mathrm{POPt}+$ et

MNM $=\pi 55^{\star}$ GDP_WORLDt $+\pi 56^{\star}$ LIFTINGt $+\pi 57^{\star}$ ERt + $\pi 58^{*}$ WOPt $+\pi 59^{*}$ GDP_INDOt $+\pi 60 *$ JIBORt + $\pi 61^{\star} \mathrm{FDIt}+\pi 62^{\star} \mathrm{INFt}+\pi 63^{*} \mathrm{POPt}+$ et

$\mathrm{RCA}=\pi 73^{\star}$ GDP_WORLDt $+\pi 74^{*}$ LIFTINGt $+\pi 75^{\star}$ ERt + $\pi 76^{*}$ WOPt $+\pi 77^{\star}$ GDP INDOt $+\pi 78^{*}$ JlBORt + $\pi 79 *$ FDIt $+\pi 80 *$ INFt $+\pi 81^{*} \mathrm{POPt}+$ et

Q_M $=\pi 91^{*}$ GDP_WORLDt $+\pi 92^{*}$ LIFTINGt $+\pi 93^{*} E R t+$ $\pi 94^{*} \mathrm{WOPt}^{-}+\pi 95^{\star} \mathrm{GDP}$ INDOt $+\pi 96^{*} \mathrm{JIBORt}+$ $\pi 97^{*}$ FDIt $+\pi 98 *$ INFt $+\pi 99^{*} \mathrm{POPt}+$ et

$\mathrm{W}=\pi 109 * \mathrm{GDP}$ WORLDt $+\pi 110 *$ LIFTINGt $+\pi 111 *$ ERt + $\pi 112^{*} \mathrm{WOPt}+\pi 113^{*} \mathrm{GDP}$ INDOt $+\pi 114^{*}$ JIBORt + $\pi 115^{\star}$ FDIt $+\pi 116^{*} \mathrm{INFt}+\pi \overline{11} 7^{*} \mathrm{POPt}+$ et

$\mathrm{Q} \_\mathrm{MC}=\pi 127^{*} \mathrm{GDP}$ WORLDt $+\pi 128^{*}$ LIFTINGt $+\pi 129 * \mathrm{ERt}$ $+\pi 130 *$ WOPt $+\pi 131^{*}$ GDP_INDOt $+\pi 132 *$ JIBORt $+\pi 133^{\star} \mathrm{FDIt}+\pi 134^{\star} \mathrm{INFt}+\pi 135^{\star} \mathrm{POPt}+$ et

GDP_CAP $=\pi 145^{\star}$ GDP_WORLDt $+\pi 146 *$ LIFTINGt + $\pi 147^{*}$ ERt $+\pi 148^{*}$ WOPt $+\pi 149 *$ GDP_INDOt + $\pi 150^{\star} \mathrm{JIBORt}+\pi 151^{*} \mathrm{FDIt}+\pi 152^{\star} \mathrm{INFt}+\pi 153^{*} \mathrm{POPt}$ + et

P_BBM $=\pi 163^{*}$ GDP_WORLDt $+\pi 164 *$ LIFTINGt + $\pi 165^{\star} \mathrm{ERt}+\pi 166^{*} \mathrm{WOPt}+\pi 167^{*} \mathrm{GDP}$ INDOt + $\pi 168^{*}$ JIBORt $+\pi 169^{*}$ FDIt $+\pi 170 *$ INFt $+\overline{\pi 171 * P O P t}$ + et

P_MINAS $=\pi 181 *$ GDP_WORLDt $+\pi 182 *$ LIFTINGt + $\pi \overline{183}{ }^{*} \mathrm{ERt}+\pi 184^{*} \mathrm{WOPt}+\pi 185^{*} \mathrm{GDP}$ INDOt + $\pi 186^{\star}$ JIBORt $+\pi 187^{\star}$ FDIt $+\pi 188^{\star}$ INFt $+\pi 189^{\star} \mathrm{POPt}+$ et 


\section{Estimation Results and Analysis}

Based on the results of data processing methods TSLS (two way SLS), the result of regression equation as in the appendix. Based on estimates, this research obtains some results as follows. First, almost all independent variables (dependent) both individual and simultaneous statistically is significant in influencing the dependent variable (independent) in each equation above. It can be seen from the probability value is smaller than the number of degree belief (prob. T-test $<=1 \%, 5 \%$ and $10 \%$, while the prob. Ftest $<=1 \%$ ). In addition, variations of the independent variables included in the model together provide a considerable influence to the variation of the independent variables above. This is evident from Adjusted R-squared value that largely has been above 0.5 . From the results of these estimates indicate that the model equations are constructed statistical research has been good.

Second, each variable has had the effect of proper direction in accordance with the principles of economic theory and empirical, especially variable value of the rupiah against the US dollar. For example, any changes in the exchange rate depreciates against the US dollar, it will have a positive impact on the level of non-oil exports rise in Indonesia, as well as the negative impact on the Indonesian non-oil imports decline. However, the depreciation of the rupiah against the US dollars produce a positive impact on oil and gas imports Indonesia. This is due during the study period, the Government was using a quota policy for national oil import needs. As the result, when the exchange rate to depreciation, the more it will weigh on oil import levels were even greater. In addition, results showed statistically estimate the exchange rate variable was significant at $1 \%$ confidence level.

Table 3 below summarizes the relationship of variable influenced the rupiah / US dollar against Indonesia's current account.

Table 3. Summary a Relation between Exchange Rate, Rupiah/ US Dollar, Against Indonesia's Current Account

\begin{tabular}{|c|c|}
\hline Notes & Estimation Results \\
\hline $\begin{array}{l}\text { Impact of Exchange } \\
\text { Rate / US Dollar } \\
\text { against the Export - } \\
\text { Import Indonesia }\end{array}$ & $\begin{array}{l}\text { Depreciating exchange rate would help } \\
\text { exports, but on the other hand will also weigh } \\
\text { on the financing imports, particularly related to } \\
\text { oil imports and higher fuel subsidies. As a } \\
\text { result, the depreciation of the rupiah } \\
\text { experienced a positive impact on the } \\
\text { performance of non-oil exports, as well as } \\
\text { degrade the performance of Indonesian non- } \\
\text { oil imports. However, depreciation is actually a } \\
\text { positive impact on oil and gas imports variable } \\
\text { Indonesia. That's because the burden of high } \\
\text { fuel subsidize resulting oil import levels are }\end{array}$ \\
\hline
\end{tabular}

\begin{tabular}{|c|c|}
\hline & $\begin{array}{l}\text { increasing (due to quota policy to fulfill the } \\
\text { needs of oil imports for domestic uses). }\end{array}$ \\
\hline $\begin{array}{l}\text { Impact of Exchange } \\
\text { Rate Rupiah / US } \\
\text { Dollar against the } \\
\text { Revealed } \\
\text { Comparative } \\
\text { Advantage }\end{array}$ & $\begin{array}{l}\text { Depreciating exchange rate should improve } \\
\text { export competitiveness of a country, because } \\
\text { the price is relatively cheaper than goods by } \\
\text { other countries. However, the decline in the } \\
\text { exchange rate (depreciation), actually reduce } \\
\text { the competitiveness of national industry due to } \\
\text { the use of raw materials are mostly imported. }\end{array}$ \\
\hline $\begin{array}{l}\text { Impact of Exchange } \\
\text { Rate I US Dollar } \\
\text { against the National } \\
\text { Fuel Prices (BBM } \\
\text { Price) }\end{array}$ & $\begin{array}{l}\text { The depreciation of the rupiah against the US } \\
\text { dollar had a positive impact for the increase in } \\
\text { fuel prices in the country due to the high } \\
\text { dependence on oil imports Indonesia. }\end{array}$ \\
\hline
\end{tabular}

\section{Simulation}

The purpose of doing the simulation is to compare the benefits of simultaneous equation model to the cost of building. With historical simulation shows that the predictive value of the Export of Oil and Gas Oil and Gas Export value closer observation, as well as the dependent variable predicted dependent variable observation approach (see chart below).

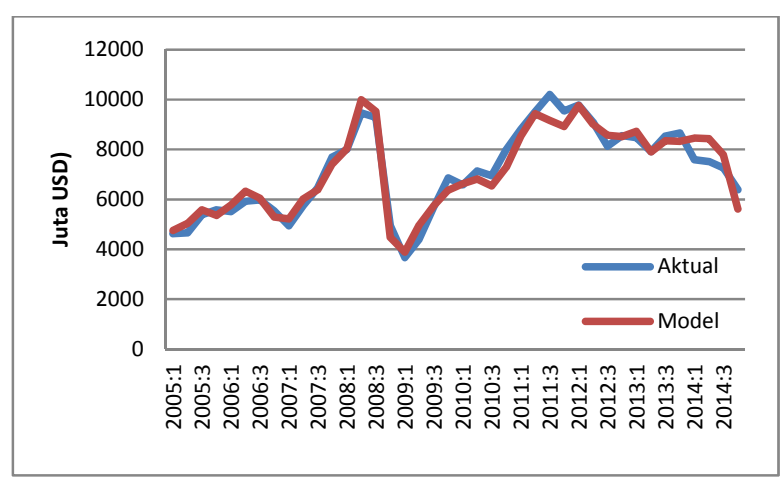

Equation 1: Export of Oil and Gas

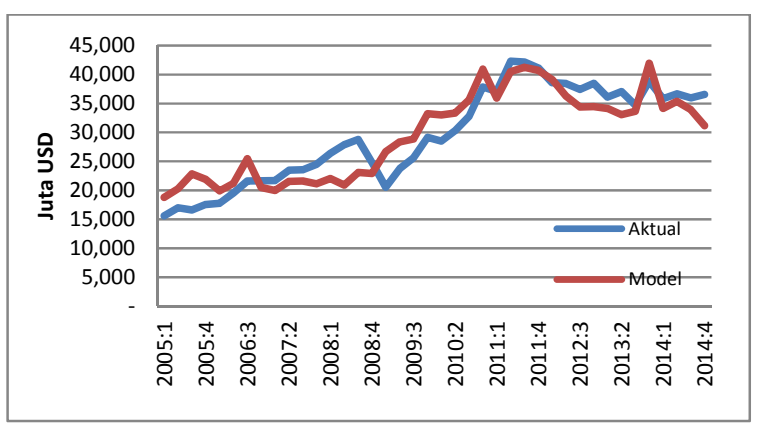

Equation 2: Export of Non Oil and Gas 

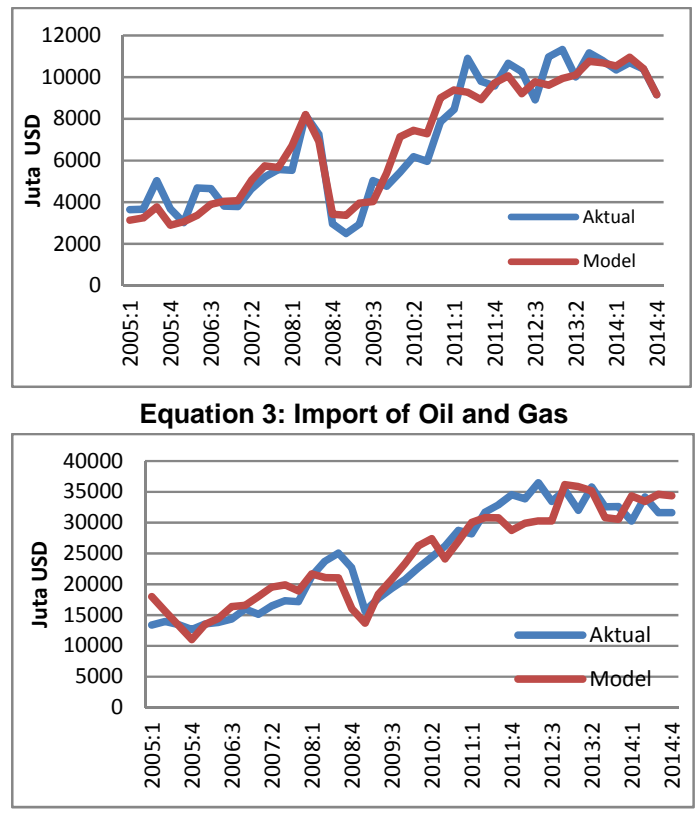

Equation 4: Import of Non Oil and Gas

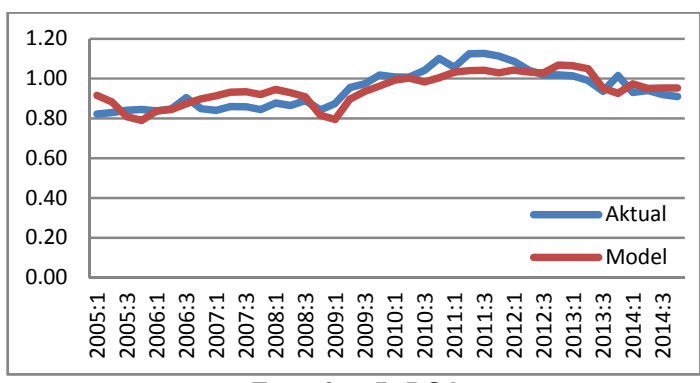

Equation 5: RCA

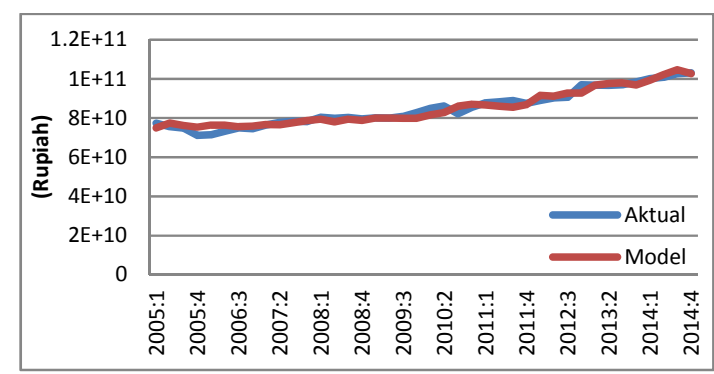

Equation 6: Total Output of Industry

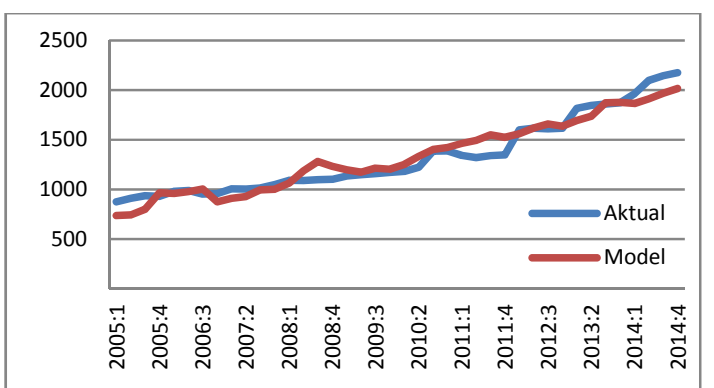

Equation 7: Wage

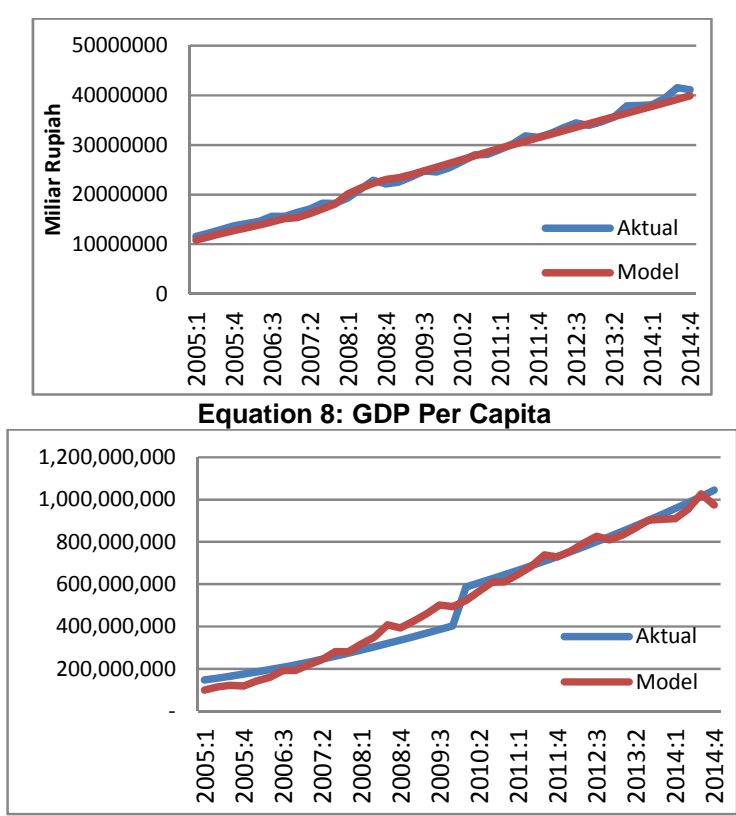

Equation 9: Number of Motor Vehicle

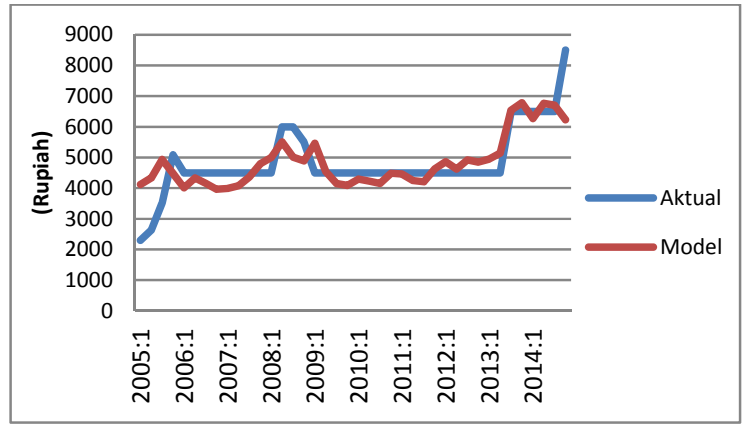

Equation 10: BBM Price

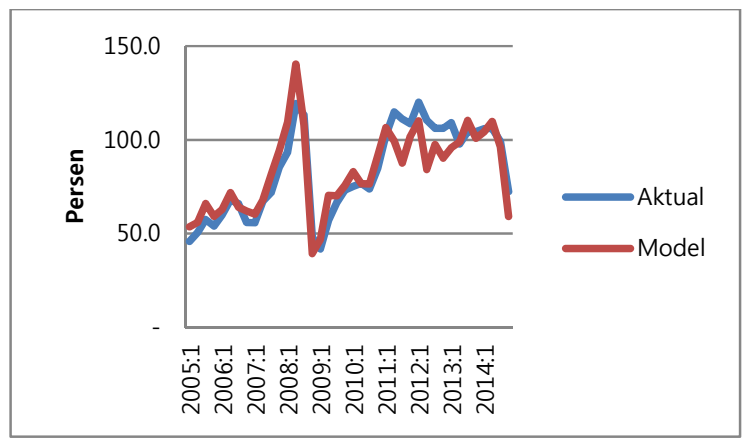

Equation 11: Indonesia Crude Oil Price

The impact of changes in the variables of the rupiah against the US dollar for the conditions of the current account balance can be seen through changes to multiple components of exports and imports as Table 4 below. 
Table 4. Impact of Changes in Exchange Rate Rupiah / US Dollar against Current Account

\begin{tabular}{|c|c|c|c|c|}
\hline \multicolumn{2}{|c|}{ Time } & \multicolumn{2}{c|}{ ER } & \multicolumn{2}{c|}{ CA } \\
\hline \multicolumn{2}{|c|}{$\mathrm{t}$} & \multicolumn{2}{c|}{9480} & \multicolumn{2}{c|}{14021} \\
\hline \multicolumn{2}{|c|}{$\mathrm{t}+1$} & 11000 & \multicolumn{2}{c|}{16797} \\
\hline Time & XM & XNM & MM & MNM \\
\hline $\mathrm{T}$ & 5337 & 22339 & 2394 & 11261 \\
\hline $\mathrm{t}+1$ & 5337 & 20407 & 2399 & 6548 \\
\hline
\end{tabular}

Based on simulation results expose, a change / volatility of the rupiah against the US dollar (ER) depreciating it, then resulted in the improvement in the current account position of Indonesia. From the side of the oil and gas sector, currency depreciation of the rupiah against the US dollar results in an increased burden of higher oil and gas imports (MM) due to import transactions which must be put on the currency of the US dollar. Nevertheless, the improvement in the current account position of Indonesia due to the weakening of the domestic industrial sector performance due to the high cost of imported raw materials. It results in a decrease in the level of non-oil import (MNM) Indonesia mainly to demand for industrial raw materials also helped reduce the level of non-oil exports (XNM) Indonesia, particularly from the sector of industrial products (Total impairment of non-oil exports was higher than the import value of non oil and gas).

\section{Conclusion}

Each of variables in this study have had the effect right direction in accordance with the principles of economic theory and empirical. Ex Pose simulation, based on results, the impact of changes in the value of the rupiah against the US dollar, on the condition of Indonesia's current account balance can be seen through changes to multiple components of exports and imports, which will eventually add up to the total current account balance as follows.

Based on estimation, the change (shock) is occurring on the variable value of the rupiah against the US dollar (ER) (depreciate) actually lead to improvement in the current account position of Indonesia. From the side of the oil and gas sector, currency depreciation of the rupiah against the US dollar resulted in an increase burden of higher oil and gas imports (MM). That is because when the rupiah depreciates against the US dollar, then the burden of the greater national oil imports meet the needs of national oil imports (government when it uses oil import quota policy based on the needs of the domestic oil). Nevertheless, the improvement in the current account position of Indonesia is due to the weakening of the domestic industrial sector performance due to the high cost of imported raw materials. Thus, reducing the level of non-oil import (MNM), mainly to industrial demand. That in turn to help reducing the level of non-oil exports (XNM), particularly in the sectors of industrial output in the country (Total impairment of non-oil import is higher than the export value of Indonesia).

As a suggestion, the government can perform the following implementation targets, adapted to the span of the implementation. In the short term, government exercises control over the low and stable inflation to maintain competitiveness through cost of fund management (low interest rates) and the cost of production (the production cost of the wage components). The results of the simulation study show that the wage component and interest rate related to the competitiveness of the domestic industry.

In the medium-term, providing tax incentives to investors who invest to build upstream and between.

In Long, priorities began to build logistics infrastructure, to encourage the creation of linkages upstream, intermediate and downstream, as well as aspects of the output distribution in the country, so as to create value added in the industrial sector.

\section{References}

Calderon, C. A., Chong, A., \& Loayza, N.V. (2002). Determinants of Current Account Deficits in Developing Countries. Contributions in Macroeconomics, 2(1), 1021-1021.

Chinn, M. D., \& Prasad, E. S. (2003). Medium-Term Determinants of Current Accounts in Industrial and Developing Countries: An Empirical Exploration. Journal of International Economics, 59(1), 47-76.

Chinn, M. D., \& Ito, H. (2007). Current Account Balances, Financial Development and Institutions: Assaying the World Saving Glut. Journal of International Money and Finance, 26(4), 546-569.

Chinn, M. D., \& Ito, H. (2008). Global Current Account Imbalances: American Fiscal Policy versus East Asian Savings. Review of International Economics, 16(3), 479-498.

Debelle, G., \& Faruqee. H. (1996). What Determines the Current Account? A cross-Sectional Panel Approach. IMF Working Paper No. 96/58. Retrieved May 1, 2018 from https://papers.ssrn.com/sol3/papers.cfm?abstract _id $=882958$

Ericsson, N. R., \& Marquez, J. (1993). Encompassing the forecasts of US trade balance models. The Review of Economics and Statistics, 75(1), 19-31.

Ferretti, G. M. M., \& Razin, A. (1998). Current Account Reversal and Currency Crisis: Empirical Regularities. 
International Monetary Fund. Retrieved May 1, 2018 from http://www.nber.org/chapters/c8695.pdf

Freund, C., \& Warnock, F. (2007). Current Account Deficits in Industrial Countries: The Bigger They Are, The Harder They Fall? In G7 Current Account Imbalances: Sustainability and Adjusment. University of Chicago Press.

Gruber, J. W., \& Kamin. S. B. (2007). Explaining the Global Pattern of Current Account Imbalances. Journal of International Money and Finance, 26(4), 500-522.

Khan, M. S., \& Knight, M. D. (1983). Determinants of Current Account Balances of Non-Oil Developing Countries in the 1970s: An Empirical Analysis. Staff Papers, 30(4), 819-842.

Krugman, P. R., (2010). International Economics: Theory and Policy. Prentice Hall: USA.

\section{Appendix}

\section{Data Sources}

\begin{tabular}{|l|l|}
\hline \multicolumn{1}{|c|}{ Variables } & \multicolumn{1}{c|}{ Sources } \\
\hline XM & Bank Indonesia \\
\hline XNM & Bank Indonesia \\
\hline MM & Bank Indonesia \\
\hline MNM & Bank Indonesia \\
\hline GDP_WORLD & IMF \\
\hline WOP & WTI \\
\hline GDP_CAP & Badan Pusat Statistik \\
\hline P_MINAS & Bank Indonesia \\
\hline LIFTING & Bank Indonesia \\
\hline ER & Bank Indonesia \\
\hline GDP_INDO & Badan Pusat Statistik \\
\hline JIBOR & Bank Indonesia \\
\hline RCA & Bank Indonesia \& IMF \\
\hline Q_M & Badan Pusat Statistik \\
\hline Q_MC & Badan Pusat Statistik \\
\hline LIFTING & Bank Indonesia \\
\hline P_BBM & Kementetrian ESDM \\
\hline FDI & Bank Indonesia \\
\hline INF & Badan Pusat Statistik \\
\hline W & Badan Pusat Statistik \\
\hline POP & Badan Pusat Statistik \\
\hline
\end{tabular}

Mann, C. L. (2002). Perspectives on the U.S. Current Account Deficit and Sustainability. Journal of Economic Perspectives, 16(3), 131-152.

Özmen, E., \& Yolcu-Karadam, D. (2014). Structural Change in Turkish External Trade: Evidence from BEC Sectors. ERC Working Paper in Economics 14/13. Retrieved May 1, 2018 from https://ideas.repec.org/p/met/ wpaper/1413.html

Pindyck, R. S., \& Rubinfeld, D. L. (1998). Econometric Models and Economic Forecasts. McGraw-Hill: New York

Satsangi, R., \& Sangar, V. (2013). Analysis of India's Current Account. University of Delhi. Retrieved May 1, 2018 from https://papers.ssrn.com/sol3/papers.cfm? abstract_id=2355738 